\title{
Strategi Guru dalam Pembelajaran Holistik pada Pendidikan Anak Usia Dini
}

\author{
Zulaecha Ngiu $^{\circledR}$, Novianty Djafri ${ }^{1}$, Arwildayanto ${ }^{3}$ \\ Manajemen Pendidikan, Universitas Negeri Gorontalo, Indonesia ${ }^{(1)}$ \\ DOI: $\underline{10.31004 / \text { obsesi.v6i3.1798 }}$
}

\begin{abstract}
Abstrak
Penting bagi guru pendidikan anak usia dini untuk memilih, menemukan dan mencari mitra yang sesuai agar anak usia golden age dapat tumbuh kembang dengan sempurna, mendapatkan pelayanan pendidikan, pembelajaran dan asuhan yang berkarakter baik. Penelitian ini bertujuan untuk memperoleh gambaran tentang strategi guru dalam pembelajaran holistik pada pendidikan anak usia dini. Penelitian ini menggunakan kuantitatif deskriptif dengan survei. Teknik analisis data dari penelitian ini menggunakan analisis deskriptif dalam bentuk tabel frekuensi dengan formula yang di persentasikan (\%). Hasil penelitian menunjukkan bahwa analisisi strategi guru dalam pembelajaran holistik pada pendidikan anak usia dini kota gorontalo dengan nilai $79.52 \%$ berada pada kategori baik. Guru dapat menggunakan strategi-strategi ini untuk mengimplementasikan PAUD HI yang berkualitas.
\end{abstract}

Kata Kunci: strategi guru; pembelajaran holistik integratif; pendidikan anak usia dini

\begin{abstract}
It is important for an early childhood education teacher for choosing, finding, and looking for best partner in addition to golden age children can grow and develop perfectly, get the education service, learning, and character parenting well. This study aimed to describe about teacher strategies in holistic learning on early childhood education. It used descriptive quantitative methods with survey. Analyze used a frequencies table with precent formula (\%). The result is teacher strategies in holistic learning on early childhood education at Gorontalo City with score $79.52 \%$ is in a good category. Teachers can use these strategies for implementing the integrative holistic with best quality.
\end{abstract}

Keywords: Teacher Strategy, Integrative Holistic Learning, Early Childhood Education

Copyright (c) 2021 Zulaecha Ngiu, et al.

$\square$ Corresponding author:

Email Address : zulaecha.ngiu@ung.ac.id (Gorontalo, Indonesia)

Received 7 May 2021, Accepted 19 September 2021, Published 20 September 2021

\section{PENDAHULUAN}

Layanan stimulasi dalam PAUD Holistik Integratif (HI) terdiri dari layanan pendidikan, kesehatan dan gizi, pengasuhan, perlindungan dan kesejahteraan (Peraturan Presiden, 2013). Kelima aspek ini harus ada dalam setiap satuan PAUD mengingat tumbuh kembang anak menjadi perhatian utama oleh pendidik. Secara holistic, PAUD berusaha untuk 
untuk melakukan pemenuhan kebutuhan kelima aspek tersebut (Nurani, 2019). Sedangkan secara integratif atau terpadu memiliki arti bahwa penanganan anak usia dini dilakukan oleh berbagai pihak baik di tingkat sekolah, rumah, masyarakat, maupun pemerintah. Hal ini dilakukan dengan tujuan untuk melahirkan generasi yang sehat, cerdas, dan berakhlak mulia. Oleh karena itu, pendidikan anak usia dini tidak hanya mengedepankan kecerdasan pengetahuan saja namun juga membelajarkan moral serta agama. Hal ini berarti, anak tidak hanya memahami literasi dan numerik, tetapi juga harus memiliki pendidikan pembelajaran karakter sehingga daapt melahirkan sumberdaya manusia unggul.

Hasil penelitian dahulu menyatakan adanya peningkatan karakter anak setelah diberikan pembelajaran holistik (Khoiriyah, 2015). Karakter tersebut ditinjau dari tiga aspek yakni kemandirian, kedisiplinan, dan tanggungjawab. Penanaman nilai karakter membutuhkan kerjasama baik orangtua, guru, masyarakat, maupun pemangku jabatan. Hal ini karena prosesnya memakan waktu yang tidak singkat serta komitmen yang kuat. Oleh karena, pendidikan karakter memang sejatinya lebih sulit dibandingkan dengan pendidikan akademik. Lebih lanjut, sebuah studi mengungkapkan bahwa dengan pembelajaran HI kebutuhan esensial anak didik terpenuhi dengan baik (Hijriyani \& Machali, 2017). Hal ini karena prinsip yang digunakan dalam PAUD HI yang disesuaikan dengan minat anak dan terjalinnya kemitraan dengan lembaga di luar sekolah membuat stimulasi perkembangan dan pertumbuhan anak menjadi lebih optimal.

Keberhasilan implementasi PAUD HI ditentukan oleh beberapa faktor diantaranya: kompetensi guru, sikap pembina/supervisor (Usnawati et al., 2016), dan dukungan keluarga (Ulfah, 2019). Kompetensi berhubungan dengan kemampuan guru untuk mengelola administrasi dan menjalin hubungan sosial dalam mengantisipasi kompetisi global. Guru yang memiliki pengetahuan dan keterampilan yang sesuai dengan kompetensinya lebih mudah mencapai keberhasilan dalam melahirkan generasi yang unggul sesuai harapan masyarakat. Oleh karena itu, peningkatan kompetensi harus dilakukan oleh setiap guru secara berkelanjutan dengan cara ikut serta dalam seminar/webinar, pelatihan, dan diskusi kelompok terutama yang berkaitan dengan implementasi PAUD HI. Di sisi lain, implementasi PAUD HI juga ditentukan oleh sikap pembina/supervisor yang memiliki komitmen kuat untuk membantu guru PAUD memahami pembelajaran holistik integratif. Mereka harus disiplin, sabar, ramah, terbuka, dan selalu memberikan solusi atas setiap permasalahan dan kekurangan dari guru. Sedangkan dukungan orangtua diperlukan agar ada kesinambungan program sekolah dengan rumah.

Meskipun pembelajaran holistik integratif memberikan efek positif terhadap peningkatan kualitas layanan pendidikan, namun sebuah penelitian menunjukkan bahwa 94\% lembaga PAUD di kota daerah Yogyakarta belum menerapkan secara maksimal (Pramudyani et al., 2017). Kebingungan guru dalam menghadapi perubahan kurikulum dan tidak dilibatkannya dalam proses pengembangan kurikulum menjadi salah satu penyebabnya. Beberapa kendala implementasi pembelajaran holistik integratif juga dilaporkan penelitian lain diantaranya rendahnya komitmen kerjasama yang rendah antar sektor terkait, kompetensi guru terkait PAUD HI, dan kesadaran orangtua untuk terlibat dalam pendidikan (Wijayanti, 2018).

Kurangnya sosialisasi dan advokasi terhadap mitra kerja dan stakeholder menyebabkan adanya kesalahpahaman terhadap tujuan yang akan dicapai terhadap program PAUD HI. Mitra kerja menganggap bahwa akan ada hak-hak yang selama ini diberikan pemerintah kepada mereka akan diambil alih oleh satuan PAUD. Dalam kondisi ini penting bagi satu PAUD untuk menjalin komunikasi sebagai salah satu kunci utama untuk meraih keberhasilan kerjasama. Lebih jauh, rendahnya keterlibatan lembaga pemerintah terhadap PAUD juga dilaporkan oleh sebuah penelitian yang menyatakan bahwa belum adanya koordinasi yang sesuai antara lembaga pemerintah dengan satuan PAUD (Akbar, 2018). Hal tersebut terlihat dari dinas social daerah yang belum memberikan bimbingan layanan pengembangan PAUD $\mathrm{HI}$, dinas kependudukan dan catatan sipil daerah yang belum memiliki program penyuluhan 
hak anak untuk memiliki identitas akta kelahiran kepada orangtua, rendahnya peran pihak kepolisian dalam memberikan penyuluhan tentang perlindungan hukum dari tindak penelantaran dan kekerasan terhadap anak. Selain itu, juga belum adanya koordinasi yang baik antara PAUD dan tokoh masyarakat setempat.

Permasalahan kompetensi guru ditinjau dari pemahaman guru terhadap PAUD HI. Hal ini karena rendahnya peningkatan kompetensi, evaluasi, dan pembinaan (Agustini, 2015). Selain itu, tumpang tinding tugas pokok guru yang merangkap sebagai tenaga kependidikan dan pendidik membuat fokus guru menjadi terpecah. Sedangkan hambatan dari keterlibatan orangtua ditinjau dari kesibukan orangtua sehingga kurang memperhatikan program pembinaan dari sekolah. Rendahnya keterlibatan orangtua mengakibatkan pemahaman terhadap hakikat PAUD yang menekankan pada konsep bermain menjadi tidak sesuai. Banyaknya orangtua yang mengutamakan aspek kognitif untuk distimulasi menyebabkan kurang sesuainya implementasi teori PAUD di sekolah.

Pembelajaran holistik integrative menyatukan segala aspek dan nilai-nilai dalam pendidikan, seperti nilai moral, etis, religiuas, psikologis, filosofis, dan sosial sebagai satu kesatuan yang menyeluruh untuk memenuhi kebutuhan esensial anak(Elyana, 2011). Keberhasilan PAUD HI ditentukan oleh dukungan dari berbagai sektor. Sekolah perlu mengidentifikasi aspek apa yang dibutuhkan agar PAUD HI dapat diimplementasikan sesuai arahan dan kebijakan sekolah beserta pemerintah daerah setempat. Hal ini karena setiap pelaksanaan PAUD HI hendaknya disesuaikan dengan karakteristik dan kebutuhan yang ada di wilayah satuan PAUD berada. Oleh karena itu, setiap guru perlu mencari strategi yang tepat agar pembelajaran yang diberikan kepada anak dapat berjalan secara holistic terintegratif.

Hambatan pelaksanaan implementasi pembelajaran HI masih ditemui di satuan PAUD seperti yang telah diuraikan di atas. Meskipun beberapa studi melaporkan adanya keberhasilan dalam pelaksanaan proses pembelajaran holistik integratif di PAUD(Laila, 2013; Oktaviani \& Dimyati, 2021; Sadiah et al., 2020; Yulianto et al., 2016), akan tetapi penelitian yang berkaitan dengan strategi guru dalam pembelajaran HI masih terbatas. Strategi penting untuk guru karena mereka adalah pemimpin kelas yang menjalankan fungsi manajemen sebagai seseorang yang profesional (Usman, 2004). Oleh karena itu, penelitian ini bertujuan untuk menggambarkan strategi bagi guru untuk mencapai kesuksesan dalam pembelajaran holistik integratif terutama di satuan PAUD.

\section{METODOLOGI}

Penelitian ini menggunakan pendekatan deskriptif kuantitatif. Metode penelitian ini dipilih karena peneliti ingin memperoleh data yang dapat menggambarkan sejauh mana guru PAUD sudah mengimplementasikan strategi-strategi yang secara teoritis dapat mempermudah mereka menerapkan implementasi pembelajaran holistik integratif. Lokasi penelitian dilakukan di tiga satuan PAUD Kota Gorontalo. Subyek penelitian terdiri dari kepala sekolah dan guru PAUD yang dipilih menggunakan teknik purposive sampling. Dari populasi yang berjumlah 159, kemudian diambil sampel sebanyak 38 orang dengan rincian 32 guru dan 5 kepala sekolah.

Teknik pengambilan data menggunakan survei dengan instrumen angket tertutup. Proses pengambilan data dilakukan dengan menyebarkan angket ke sekolah. Terlebih dahulu peneliti meminta kesediaan guru dan kepala sekolah untuk menjadi partisipan dalam penelitian dengan menggunakan surat resmi dari universitas. Instrumen yang digunakan dirumuskan dari definisi operasional terkait dengan strategi guru dalam pembelajaran holistik integratif. Indikator dalam instrumen dapat dilihat pada Tabel 1. Data yang telah terkumpul kemudian dianalisis menggunakan analisis deskriptif dalam bentuk tabel frekuensi. Hasil perhitungan kemudian ditentukan kriterianya dengan merujuk pada Tabel 2. 
Tabel 1. Indikator Instrumen Penilaian (IP)

\begin{tabular}{cl}
\hline No & \multicolumn{1}{c}{ Indikator } \\
\hline $\mathbf{1}$ & Guru mentransformasi pembelajaran pada anak usia dini. \\
$\mathbf{2}$ & $\begin{array}{l}\text { Guru memiliki rencana tindakan (rangkaian kegiatan untuk sistem pembelajaran holistik } \\
\text { anak usia dini) }\end{array}$ \\
$\mathbf{3}$ & Guru mengukur keberhasilan anak usia dini dalam mentransfer pembelajaran holistik \\
$\mathbf{4}$ & Guru lebih fleksibel dalam pelaksanaan proses pembelajaran \\
$\mathbf{5}$ & $\begin{array}{l}\text { Guru melaksanakan pembelajaran holistik melalui pelatihan guru penggerak sehingga } \\
\text { dapat mentransformasi pembelajaran kepada anak usia dini. }\end{array}$ \\
$\mathbf{6}$ & Kepala sekolah menjalankan misi secara efektif \\
$\mathbf{7}$ & $\begin{array}{l}\text { Guru menyederhanakan kurikulum yang fleksibel sesuai dengan kompetensi } \\
\text { kemampuan siswa }\end{array}$ \\
$\mathbf{8}$ & $\begin{array}{l}\text { Pembelajaran didasarkan pada asesmen untuk mengukur personalisasi segmentasi } \\
\text { pembelajaran }\end{array}$ \\
$\mathbf{9}$ & $\begin{array}{l}\text { Guru menjalin kolaborasi kinerja sekolah untuk kemitraan daerah dan masyarakat } \\
\mathbf{1 0}\end{array}$ \\
\hline
\end{tabular}

Tabel 2. Kualifikasi kriteria

\begin{tabular}{ccc}
\hline No & Rentang Skor \% & Kriteria \\
\hline $\mathbf{1}$ & $91-100$ & Sangat Baik \\
$\mathbf{2}$ & $76-90$ & Baik \\
$\mathbf{3}$ & $51-75$ & Cukup Baik \\
$\mathbf{4}$ & $\leq 50$ & Tidak Baik. \\
\hline
\end{tabular}

(Sumber: (Sugiyono, 2013)

\section{HASIL DAN PEMBAHASAN}

Data yang telah dianalisis menggunakan metode deskriptif dan merujuk pada Tabel 2. sebagai kualifikasi kriteria menunjukkan bahwa strategi guru dalam pembelajaran holistik integratif dengan nilai 79.52\% berada dalam kategori baik. Dari Gambar 1. Diperoleh data bahwa strategi paling banyak dilakukan guru adalah melaksanakan pembelajaran holistik melalui pelatihan guru penggerak sehingga dapat mentransformasi pembelajaran kepada anak usia dini $(83,16 \%)$ dan menyiapkan standar penilaian global $(83,16 \%)$. Sedangkan strategi dengan nilai minimal adalah kepala sekolah menciptakan SDM yang unggul (70,53\%).

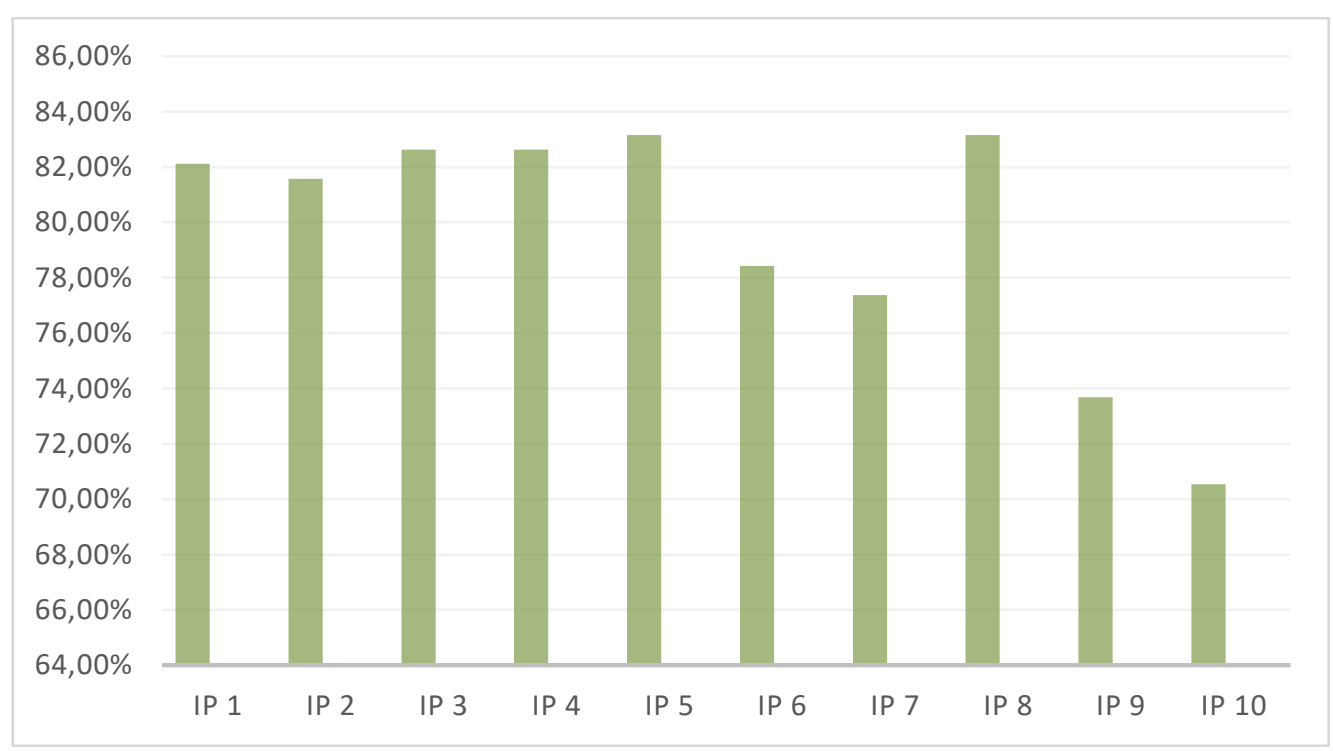

IP = Indikator Penilaian 
Meskipun hasil keseluruhan dinyatakan baik namun jika dilihat dari tabel perindikator penilaian, masih ada lembaga atau satuan PAUD yang kadang-kadang atau jarang menerapkan strategi tersebut. Strategi yang masih rendah dilakukan dengan nilai 44,74\% (kategori kadang-kadang) adalah menjalin kolaborasi kinerja sekolah untuk kemitraan daerah dan masyarakat.

Tabel 3. IP 1: Guru Mentransformasi Pembelajaran pada Anak Usia Dini

\begin{tabular}{cccccccc}
\hline $\begin{array}{c}\text { Alternatif } \\
\text { Jawaban }\end{array}$ & Bobot & Frekuensi & $\begin{array}{c}\text { Skor } \\
\text { Capaian }\end{array}$ & $\begin{array}{c}\text { Persentase } \\
(\%)\end{array}$ & $\begin{array}{c}\text { Skor } \\
\text { Maksimal }\end{array}$ & $\begin{array}{c}\text { Persentase } \\
\text { Pernyataan }\end{array}$ & Kategori \\
\hline Selalu & 5 & 13 & 65 & 34,21 & & & \\
Sering & 4 & 16 & 64 & 42,11 & & & \\
Kadang & 3 & 9 & 27 & 23,68 & 190 & $82,11 \%$ & Baik \\
Jarang & 2 & 0 & 0 & 0.00 & & & \\
Tdk Pernah & 1 & 0 & 0 & 0,00 & & & \\
\hline Total & 38 & 156 & 100,00 & & \\
\hline \multicolumn{7}{c}{ Sumber: Data diolah, 2021 }
\end{tabular}

Tabel 4. IP2: Guru Memiliki Rencana Tindakan

\begin{tabular}{cccccccc}
\hline $\begin{array}{c}\text { Alternatif } \\
\text { Jawaban }\end{array}$ & Bobot & Frekuensi & $\begin{array}{c}\text { Skor } \\
\text { Capaian }\end{array}$ & $\begin{array}{c}\text { Persentase } \\
(\%)\end{array}$ & $\begin{array}{c}\text { Skor } \\
\text { Maksimal }\end{array}$ & $\begin{array}{c}\text { Persentase } \\
\text { Pernyataan }\end{array}$ & Kategori \\
\hline Selalu & 5 & 13 & 65 & 34,21 & & & \\
Sering & 4 & 16 & 64 & 42,11 & & & \\
Kadang & 3 & 8 & 24 & 21,05 & 190 & $81,58 \%$ & Baik \\
Jarang & 2 & 1 & 2 & 2,63 & & & \\
Tdk Pernah & 1 & 0 & 0 & 0,00 & & & \\
\hline Total & 38 & 155 & 100,00 & &
\end{tabular}

Tabel 4. IP3: Guru dapat Mengukur Keberhasilan Anak Usia Dini dalam Mentransfer Pembelajaran Holistik

\begin{tabular}{cccccccc}
\hline $\begin{array}{c}\text { Alternatif } \\
\text { Jawaban }\end{array}$ & Bobot & Frekuensi & $\begin{array}{c}\text { Skor } \\
\text { Capaian }\end{array}$ & $\begin{array}{c}\text { Persentase } \\
(\%)\end{array}$ & $\begin{array}{c}\text { Skor } \\
\text { Maksimal }\end{array}$ & $\begin{array}{c}\text { Persentase } \\
\text { Pernyataan }\end{array}$ & Kategori \\
\hline Selalu & 5 & 1 & 60 & 31,58 & & & \\
Sering & 4 & 19 & 76 & 50,00 & & & \\
Kadang & 3 & 7 & 21 & 18,42 & 190 & $82,63 \%$ & Baik \\
Jarang & 2 & 0 & 0 & 0,00 & & & \\
Tidak Pernah & 1 & 0 & 0 & 0,00 & & & \\
\hline Total & & \multicolumn{7}{c}{ Sumber: Data diolah, 2021} & &
\end{tabular}

Tabel 5. IP4: Guru Lebih Fleksibel dalam Pelaksanaan Proses Pembelajaran

\begin{tabular}{cccccccc}
\hline $\begin{array}{c}\text { Alternatif } \\
\text { Jawaban }\end{array}$ & Bobot & Frekuensi & $\begin{array}{c}\text { Skor } \\
\text { Capaian }\end{array}$ & $\begin{array}{c}\text { Persentase } \\
(\mathbf{\%})\end{array}$ & $\begin{array}{c}\text { Skor } \\
\text { Maksimal }\end{array}$ & $\begin{array}{c}\text { Persentase } \\
\text { Pernyataan }\end{array}$ & Kategori \\
\hline Selalu & 5 & 13 & 65 & 34,21 & & & \\
Sering & 4 & 17 & 68 & 42,11 & & & \\
Kadang & 3 & 8 & 24 & 23,68 & 190 & $82,63 \%$ & Baik \\
Jarang & 2 & 0 & 0 & 23,68 & & & \\
Tdk Pernah & 1 & 0 & 0 & 0,00 & & \\
\hline Total & & 38 & 157 & 100,00 & & \\
\hline
\end{tabular}

Sumber: Data diolah, 2021 
Tabel 6. IP5: Guru Melaksanakan Pembelajaran Holistik Melalui Pelatihan Guru Penggerak Sehingga dapat Mentransformasi Pembelajaran kepada Anak Usia Dini

\begin{tabular}{cccccccc}
\hline $\begin{array}{c}\text { Alternatif } \\
\text { Jawaban }\end{array}$ & Bobot & Frekuensi & $\begin{array}{c}\text { Skor } \\
\text { Capaian }\end{array}$ & $\begin{array}{c}\text { Persentase } \\
\mathbf{( \% )}\end{array}$ & $\begin{array}{c}\text { Skor } \\
\text { Maksimal }\end{array}$ & $\begin{array}{c}\text { Persentase } \\
\text { Pernyataan }\end{array}$ & Kategori \\
Selalu & 5 & 15 & 75 & 39,47 & & & \\
Sering & 4 & 14 & 56 & 36,84 & & \\
Kadang & 3 & 9 & 27 & 23,68 & 190 & $83,16 \%$ & Baik \\
Jarang & 2 & 0 & 0 & 0,00 & & \\
Tdk Pernah & 1 & 0 & 0 & 0,00 & & \\
\hline Total & 38 & 156 & 100,00 & &
\end{tabular}

Tabel 7. IP6: Kepala Sekolah Menjalankan Misi secara Efektif dan Efisien

\begin{tabular}{cccccccc}
\hline $\begin{array}{c}\text { Alternatif } \\
\text { Jawaban }\end{array}$ & Bobot & Frekuensi & $\begin{array}{c}\text { Skor } \\
\text { Capaian }\end{array}$ & $\begin{array}{c}\text { Persentase } \\
(\%)\end{array}$ & $\begin{array}{c}\text { Skor } \\
\text { Maksimal }\end{array}$ & $\begin{array}{c}\text { Persentase } \\
\text { Pernyataan }\end{array}$ & Kategori \\
\hline Selalu & 5 & 12 & 60 & 31,58 & & & \\
Sering & 4 & 11 & 44 & 28,95 & & & Baik \\
Kadang & 3 & 15 & 45 & 39,47 & 190 & $78,42 \%$ & \\
Jarang & 2 & 0 & 0 & 0,00 & & \\
Tdk Pernah & 1 & 0 & 0 & 0,00 & & \\
Total & & 38 & 156 & 100,00 & & \\
\hline \multicolumn{7}{c}{ Sumber: Data diolah, 2021 }
\end{tabular}

Tabel 8. IP7: Guru Telah Menyederhanakan Kurikulum yang Fleksibel Sesuai dengan Kompetensi Kemampuan Anak Usia Dini

\begin{tabular}{cccccccc}
\hline $\begin{array}{c}\text { Alternatif } \\
\text { Jawaban }\end{array}$ & Bobot & Frekuensi & $\begin{array}{c}\text { Skor } \\
\text { Capaian }\end{array}$ & $\begin{array}{c}\text { Persentase } \\
\mathbf{( \% )}\end{array}$ & $\begin{array}{c}\text { Skor } \\
\text { Maksimal }\end{array}$ & $\begin{array}{c}\text { Persentase } \\
\text { Pernyataan }\end{array}$ & Kategori \\
\hline Selalu & 5 & 12 & 60 & 31,58 & & & \\
Sering & 4 & 12 & 48 & 31,58 & & & \\
Kadang & 3 & 11 & 33 & 28,95 & 190 & $77,37 \%$ & Baik \\
Jarang & 2 & 3 & 6 & 7,89 & & & \\
Tdk Pernah & 1 & 0 & 0 & 0,00 & & \\
\hline Total & & 38 & 147 & 100,00 & &
\end{tabular}

Tabel 9. IP8: Pembelajaran Didasarkan pada Asesmen untuk Mengukur Personalisasi Segmentasi Pembelajaran

\begin{tabular}{cccccccc}
\hline $\begin{array}{c}\text { Alternatif } \\
\text { Jawaban }\end{array}$ & Bobot & Frekuensi & $\begin{array}{c}\text { Skor } \\
\text { Capaian }\end{array}$ & $\begin{array}{c}\text { Persentase } \\
(\mathbf{\%})\end{array}$ & $\begin{array}{c}\text { Skor } \\
\text { Maksimal }\end{array}$ & $\begin{array}{c}\text { Persentase } \\
\text { Pernyataan }\end{array}$ & Kategori \\
\hline Selalu & 5 & 14 & 70 & 34,21 & & & \\
Sering & 4 & 16 & 64 & 42,11 & & & Baik \\
Kadang & 3 & 8 & 24 & 23,68 & 190 & $82,11 \%$ & \\
Jarang & 2 & 0 & 0 & 23,68 & & & \\
Tdk Pernah & 1 & 0 & 0 & 0,00 & & \\
\hline Total & 38 & 158 & 100,00 & &
\end{tabular}

Tabel 10. IP9: Guru Merjalin Kolaborasi Kinerja Sekolah untuk Kemitraan Daerah dan Masyarakat

\begin{tabular}{cccccccc}
\hline $\begin{array}{c}\text { Alternatif } \\
\text { Jawaban }\end{array}$ & Bobot & Frekuensi & $\begin{array}{c}\text { Skor } \\
\text { Capaian }\end{array}$ & $\begin{array}{c}\text { Persentase } \\
\mathbf{( \% )}\end{array}$ & $\begin{array}{c}\text { Skor } \\
\text { Maksimal }\end{array}$ & $\begin{array}{c}\text { Persentase } \\
\text { Pernyataan }\end{array}$ & Kategori \\
\hline Selalu & 5 & 5 & 25 & 13,16 & & & \\
Sering & 4 & 16 & 64 & 42,11 & & & \\
Kadang & 3 & 17 & 51 & 44,74 & 190 & $73,68 \%$ & Baik \\
Jarang & 2 & 0 & 0 & 0,00 & & & \\
Tdk Pernah & 1 & 0 & 0 & 0,00 & & \\
\hline Total & & 38 & 140 & 100,00 & &
\end{tabular}


Tabel 11. IP10: Guru Membentuk Serangkain Proses Karakter dari Hasil Serangkaian Perbuatan Timbal Balik Guru dan Siswa atas dasar Situasi Edukatif

\begin{tabular}{cccccccc}
\hline $\begin{array}{c}\text { Alternatif } \\
\text { Jawaban }\end{array}$ & Bobot & Frekuensi & $\begin{array}{c}\text { Skor } \\
\text { Capaian }\end{array}$ & $\begin{array}{c}\text { Persentase } \\
\mathbf{( \% )}\end{array}$ & $\begin{array}{c}\text { Skor } \\
\text { Maksimal }\end{array}$ & $\begin{array}{c}\text { Persentase } \\
\text { Pernyataan }\end{array}$ & Kategori \\
\hline Selalu & 5 & 5 & 25 & 13,16 & & & \\
Sering & 4 & 12 & 48 & 31,58 & & & \\
Kadang & 3 & 19 & 57 & 50,00 & 190 & $70,53 \%$ & Baik \\
Jarang & 2 & 2 & 4 & 5,26 & & \\
Tdk Pernah & 1 & 0 & 0 & 0,00 & & \\
\hline Total & & 38 & 134 & 100,00 & &
\end{tabular}

Sebesar 75,32\% guru telah mentransformasi pembelajaran pada anak. Pembelajaran transformatif menghendaki adanya perubahan cara berpikir pada anak atau dapat dikatakan model pembelajaran yang tidak menghendaki keberpusatan pada guru (Rosmilawati, 2017). Guru berusaha untuk mendidik mereka menjadi individu yang otonom dan bertanggungjawab. Hasil belajar pembelajaran transformatif tidak selalu berhubungan dengan pengetahuan dan keterampilan yang sulit dikuasi anak tetapi lebih kepada bagaimana anak memiliki keterampilan untuk berkomunikasi. Anak dapat mengemukakan dan berargumen atas idenya dan memberi bukti dan alasan akan idenya tersebut. Pada intinya, hasil belajar transformatif berhubungan dengan perubahan personal setiap individu yang kompleks. Jika kita berbicara anak usia dini, maka hasil pembelajaran transformatif mencakup berkembangnya keenam aspek perkembangan secar optimal.

Hasil penelitian menunjukkan bahwa strategi yang paling banyak dilakukan atau sering adalah melaksanakan pembelajaran holistik melalui pelatihan guru penggerak sehingga dapat mentransformasi pembelajaran kepada anak usia dini (83,16\%). Senada dengan hasil penelitian terdahulu yang melaporkan bahwa pelatihan memiliki pengaruh dalam peningkatan kompetendi profesional pendidik PAUD (Witarsa, 2015). Khususnya untuk guru yang belum memiliki latar belakang pendidik S1 PAUD, tentu mereka sangat membutuhkan pelatihan agar proses pembelajaran yang dilakukan sesuai dengan karakteristik belajar anak (Mamahit et al., 2020). Di sisi lain, dengan adanya pogram guru penggerak dimana pelatih

Sebanyak 76,32 \% guru melaporkan bahwa mereka memiliki rencana tindakan untuk mengimplementasikan pembelajaran holistik pada anak usia dini. Pembelajaran yang holistik dilakukan dengan memperhatikan keenam aspek perkembangan anak. Guru harus menyediakan serangkaian kegiatan setiap harinya untuk menstimulasi aspek tersebut. Konsep holistik juga dapat dilakukan dengan cara memberikan satu kegiatan untuk menstimulasi beberapa aspek perkembangan. Penyusunan rencana pembelajaran di kelas tidak memisahkan antara satu ilmu aspek perkembangan dengan yang lain. Sayangnya studi terdahulu melaporkan bahwa guru merasa terbebani dengan penyusunan pembelajaran (Lestari et al., 2020). Banyaknya urusan administratif yang yang dipegang oleh guru PAUD menyebabkan tidak maksimalnya penyusunan kegiatan yang dapat menstimulasi seluruh aspek perkembangan anak. Jika peran guru sebagai administrator berjalan baik, maka peran sebagai pelaksana pembelajaran belum dapat maksimal.

Sebanyak 76,32\% guru lebih fleksibel dalam proses pembelajaran. Fleksibel memiliki makna bahwa ketika melaksanakan PAUD HI, guru harus mampu berperan sebagai pendidik maupun sebagai seseorang yang menjalin kerjasama dengan pihak-pihak yang berpengaruh terhadap kehidupan anak. Sebagai pendidik, mereka harus memiliki sikap sesuai karakter umum guru PAUD (ramah, penyayang, dan mampu memotivasi anak), memberi kesempatan pada anak untuk mengembangkan potensinya, membentuk karakter anak, menggunakan benda konkret, dan memberikan pembelajaran yang bersifat kontekstual (Madjid, 2011). 
Selain itu, guru juga harus mampu menjalin komunikasi dan kemitraan baik dengan orangtua, masyarakat, maupun lembaga pemangku kepentingan/kebijakan terkait.

Salah satu program keerjasama dengan orang tua adalah melalui program parenting. Program tersebut diisi dengan kegiatan seperti yang pertama adalah KPO (Kelompok Pertemuan Orangtua). KPO memiliki program penyuluhan, diskusi, simulasi, seminar tentang pertumbuhan dan perkembangan anak, pengenalan makanan lokal yang sehat, pembiasaan perilaku Holistik Integratifdup bersih dan sehat (PHBS), penanggulangan kecacingan, penggunaan garam beryodium, pencegahan penyakit menular, dan lain-lain. Kedua, konsultasi antara guru dan orangtua berkaitan dengan pertumbuhan dan perkembangan anak. Ketiga, keterlibatan orangtua di dalam kelas misalnya membantu menata lingkungan main, membuat media pembelajaran, menjadi model profesi sesuai dengan tema pembelajaran. Keempat, keterlibatan orangtua dalam menyediakan program makan bersama secara bergilir sesuai rekomendasi ahli gizi tentang penyediaan menu makanan dengan pemenuhan gizi seimbang. Kelima, keterlibatan orangtua di luar kelas misalnya menjadi panitia kegiatan lapangan, dan menyediakan PMT. Keenam, kegiatan bersama keluarga

Selanjutnya, 63,16\% guru menyatakan bahwa mereka telah menyederhanakan kurikulum agar sesuai dengan kompetensi anak usia dini. Hal ini penting dilakukan mengingat kurikulum merupakan suatu bentuk respon pendidikan terhadap kebutuhan masyarakat dalam membangun generasi penerus (Muamanah, 2020). Oleh karena itu, kurikulum satuan pendidihan hendaknya terus dilakukan evaluasi dan perubahan apakah sudah sesuai dengan tuntutan zaman atau belum. Selain itu, penyusunan kurikulum juga harus memperhatikan karakteristik daerah agar mudah dikenali oleh anak.

Analisis data menunjukkan bahwa sebanyak 76,32\% secara konsisten melakukan asesmen atau penilaian untuk melihat apakah pembelajaran yang mereka lakukan sudah memiliki dampak pada perkembangan dan pertumbuhan anak. Hal ini menunjukkan bahwa guru memiliki kompetensi penilaian yang baik. Berbanding terbalik dengan penelitian terdahulu yang menyatakan bahwa penguasaan asesmen pembelajaran guru PAUD memiliki kategori rendah meskipun sudah memenuhi kualifikasi akademik dan pernah mengikuti pelatihan (Nurhayati \& Rakhman, 2017). Dalam penelitian tersebut, guru menganggap bahwa asesmen pembelajaran dilakukan ketika akan pembagian rapor saja. Anggapan ini jelas tidak sesuai sebab asesmen dilakukan setiap hari agar tercapai peningkatan kualitas belajar dan hasilnya.

Sayangnya, hampir setengah atau sekitar $44,74 \%$ partisipan menyatakan bahwa mereka belum secara terjadwal melakukan kemitraan dengan lembaga daerah dan masyarakat. Senada dengan penelitian sebelumnya yang menyatakan bahwa salah satu penyebab rendahnya kondisi mutu layanan PAUD HI adalah kurang atau lemahnya jalinan sinergitas antara pengelola / pendidik dengan orangtua, lembaga daerah, LSM, maupun masyarakat (Hajati, 2018). Sebaik apapun program yang telah disusun oleh sekolah apabila tidak memperoleh dukungan dari pihak-pihak yang berpengaruh terhadap kehidupan anak maka tidak akan mencapai tujuan yang telah ditetapkan. Bahkan lebih buruk lagi, jika sekolah tidak mencoba menggandeng kemitraan maka dapat diibaratkan hidup tetapi tidak bergerak. Pendidikan dilakukan seadanya dan berakibat tidak terpenuhinya hak-hak anak untuk memperoleh stimulasi pertumbuhan dan perkembangan.

Lebih jauh, 50\% guru menunjukkan bahwa mereka hanya kadang-kadang memberikan pendidikan karakter pada anak. Kondisi ini kurang memberikan dampak positif bagi anak mengingat hasil penelitian terdahulu menyatakan bahwa perubahan karakter merupakan salah satu dampak yang dihasilkan dari pembelajaran holistik (Latifah \& Hernawati, 2009). Oleh karena itu, kondisi yang ada pada hasil penelitian ini kurang bisa mendukung program pembelajaran holistik secara optimal karena pendidikan karakter hanya tidak dilakukan secara konsisten. 
Belum adanya data terkait topik penelitian dengan pihak yang menjalin kemitraan dengan sekolah menjadi salah satu kelemahan dalam penelitian kami. Data yang diperoleh hanya didasarkan pada satu perspektif yakni guru. Penelitian selanjutnya perlu menggali informasi kepada pihak-pihak di luar sekolah untuk mensinkronkan apakah pernyataan yang diberikan guru sudah sesuai dengan implementasi sesungguhnya. Metode penelitian selanjutnya juga lebih kami sarankan untuk menggunakan kualitatif agar data yang terkumpul lebih detail.

\section{SIMPULAN}

Implementasi PAUD holistik integratif membutuhkan sumber daya manusia yang mumpuni agar tujuan seperti mewujudkan anak sehat, cerdas, ceria dan memiliki akhlak yang mulia dapat tercapai. Untuk itu, guru membutuhkan strategi pembelajaran atau perencanaan yang berisi tentang rangkaian kegiatan yang sistematis. Mereka perlu mempertimbangkan metode dan memanfaatkan berbagai sumber daya atau kekuatan dalam pembelajaran. Selain itu, perlu dirumuskan tujuan yang jelas yang dapat diukur keberhasilannya karena tujuan adalah ruhnya dalam implementasi suatu strategi. Implikasi dari hasil ini adalah guru dapat menggunakan strategi-strategi yang ada di atas untuk mengimplementasikan PAUD HI yang berkualitas.

\section{UCAPAN TERIMA KASIH}

Penulis mengucapkan terimakasih kepada semua pihak yang telah membantu kegitan penelitian ini. Secara khusus, kami berterimakasih kepada guru dan kepala sekolah yang menjadi partisipan dari wilayah Kota Gorontalo. Selain itu, penulis juga berterimakasih kepada dosen-dosen Universitas negeri Gorontalo yang telah memberi dukungan sehingga artikel jurnal ini dapat selesai dan bermanfaat.

\section{DAFTAR PUSTAKA}

Agustini, S. R. I. (2015). Implementasi Pendiidkan Holistik Integratif pada Anak Usia Dini. In Tesis. STAIN Jurai Siwo Metro.

Akbar, R. A. (2018). Evaluasi Program Pengembangan Anak Usia Dini Holistik Integratif Pada Satuan PAUD. AWLADY: Jurnal Pendidikan Anak, 4(2), 137. https://doi.org/10.24235/awlady.v4i2.2703

Elyana, L. (2011). Kurikulum Holistik Integratif Anak Usia Dini dalam Implementasi Self Regulated Learning. IKIP Veteran Semarang.

Hajati, K. (2018). Pelaksanaan Pendidikan Holistik-Integratif dalam Pelayanan Kebutuhan Dasar Anak Usia Dini di Kabupaten Mamuju Sulawesi-Barat. Indonesian Journal of Educational Science (IJES), 1(1), 17-24. https:// doi.org/10.31605/ijes.v1i1.133

Hijriyani, Y. S., \& Machali, I. (2017). Pembelajaran Holistik - Integratif Anak Usia Dini dengan Pendekatan Cashflow Quadrant di RA Al Muttaqin Tasikmalaya. Al-Athfal: Jurnal Pendidikan Anak, 3(2), 119-134. https:// doi.org/10.14421/al-athfal.2017.32-02

Khoiriyah, N. (2015). Penggunaan Strategi Pembelajaran Holistik untuk Menumbuhkan Karakter Anak Usia Dini di RA An Nisa' Kedawung Tahun Ajarn 2014/2015. Naskah Publikasi Ilmiah, 32.

Laila, L. Z. I. (2013). Penyelenggaraan Program PAUD Holistik Integratif di PAUD Siwi Kencana Kota Semarang. Journal of Nonformal Education and Community Empowerment, 2(1), 73-83.

Latifah, M., \& Hernawati, N. (2009). Dampak Pendidikan Holistik pada Pembentukan Karakter dan Kecerdasan Majemuk Anak Usia Prasekolah. Jurnal Ilmu Keluarga Dan Konsumen, 2(1), 32-40. https:/ / doi.org/10.24156/jikk.2009.2.1.32

Lestari, R. H., Sumitra, A., Nurunnisa, R., \& Fitriawati, M. (2020). Perancangan Perencanaan Pembelajaran Anak Usia Dini Melalui Sistem Informasi Berbasis Website. Jurnal 
Obsesi : Jurnal Pendidikan Anak Usia Dini, 5(2), 1396-1408. https://doi.org/10.31004/obsesi.v5i2.770

Madjid. (2011). Mendesain Model Inovatif Progresif. Rizqi Press.

Mamahit, H. C., Lisa, C., Wati, S., \& Wijayanti, S. H. (2020). Pelatihan Peningkatan Kompetensi Guru PAUD di Kecamatan Cabang Bungin Kabupaten Bekasi. Jurnal Pengabdian Masyarakat Ilmu Keguruan Dan Pendidikan (JPM-IKP), 3(1), 9-17.

Muamanah, H. (2020). Implementasi Kurikulum Holistik-Integratif untuk Meningkatkan Mutu Pendidikan di SDIT LHI. Journal of Islamic Education (JIE), V(1), 1-19.

Nurani, Y. (2019). Pembelajaran 1. Layanan PAUD Holistik Integratif. Modul 1 PPG bagi Guru PAUD tahun 2019. Kemendikbud, 9-41.

Nurhayati, S., \& Rakhman, A. (2017). Studi Kompetensi Guru PAUD dalam Melakukan Asesmen Pembelajaran dan Perkembangan Anak Usia Dini di Kota Cimahi. Jurnal Pendidikan Anak, 6(2), 109-120. https://doi.org/10.21831/jpa.v6i2.17699

Oktaviani, D. A., \& Dimyati, D. (2021). Penerapan PAUD Holistik Integratif pada Masa Pandemi Covid 19. Jurnal Obsesi : Jurnal Pendidikan Anak Usia Dini, 5(2), 1870-1882. https://doi.org/10.31004/obsesi.v5i2.995

Pramudyani, A. V. R., Kurniawan, M. R., Rasyid, H., \& Sujarwo. (2017). Kurikulum Holistik Integratif Berbasis Permainan Tradisional pada PAUD di Yogyakarta. Jurnal Penelitian Ilmu Pendidikan, 10(2), 86-96. https://doi.org/10.21831/jpipfip.v10i2.17910

Rosmilawati, I. (2017). Konsep Pengalaman Belajar dalam Perspektif Transformatif: Antara Mezirow dan Freire. Prosiding Seminar Nasional Pendidikan FKIP UNTIRTA, 317-326.

Sadiah, G. S., Romadhona, N. F., \& Gustiana, A. D. (2020). Penerapan Layanan Kesehatan Dan Gizi dalam Penyelenggaraan PAUD Holistik Integratif di TK Alam Pelopor Rancaekek. Edukid, 17(1), 50-64. https:// doi.org/10.17509/edukid.v17i1.24260

Sugiyono. (2013). Metode Penelitian Pendidikan Pendekatan Kuantitatif, Kualitatif, dan R\&D. Alfabeta.

Ulfah, M. (2019). Pendekatan Holistik Integratif Berbasis Penguatan Keluarga pada Pendidikan Anak Usia Dini Full Day. Jurnal Obsesi : Jurnal Pendidikan Anak Usia Dini, 4(1), 10. https://doi.org/10.31004/obsesi.v4i1.255

Usman, H. (2004). Manajemen Pendidikan. Pascasarjana UNY.

Usnawati, N., Setiyani, A., \& Subagyo. (2016). Pembinaan PAUD Holistik Integratif dalam Perspektif Pencapaian Target SDIDTK. Jurnal Penelitian Kesehatan Suara Forikes, VII(3), 131-135.

Wijayanti, U. T. (2018). Kendala-Kendala BKB (Bina Keluarga Balita) Holistik Integratif di Provinsi Sulawesi Utara. Jurnal Komunikasi, 10(1), 65. https:// doi.org/10.24912/jk.v10i1.205

Witarsa, R. (2015). Pengembangan Program Pelatihan untuk Meningkatkan Kompetensi Guru dalam Memfasilitasi Keterampilan Berpikir Kritis Anak Usia Dini. Tunas Siliwangi, 1(1), 46-62. $\quad$ http://e-journal.stkipsiliwangi.ac.id/index.php/tunassiliwangi/article/view/91

Yulianto, D., Lestariningrum, A., \& Utomo, H. B. (2016). Analisis Pembelajaran Holistik Integratif pada Anak di Taman Kanak-kanak Negeri Pembina Grogol kabupaten kediri. Jurnal Pendidikan Usia Dini. 10, 2 (Nov. 2016), 277 - 294. https://doi.org/10.21009/JPUD.102.05 